\title{
Characterization, antioxidant and anticoagulant properties of exopolysaccharide from marine microalgae
}

\author{
Zahra Mousavian, Maliheh Safavi, , Farzaneh Azizmohseni, Mahnaz Hadizadeh and Saeed Mirdamadi* (0)
}

\begin{abstract}
The sulfated exopolysaccharide extracted from marine microalgae attracted considerable attention from both the nutraceutical and pharmaceutical industries. In the present study biomass of five marine microalgae were screened to find strains with high capacity for the production of sulfated exopolysaccharides. The anticoagulant and antioxidant activities of extracted sulfated polysaccharides were evaluated using activated partial thromboplastin time (aPTT), prothrombin time (PT), DPPH and ABTS assays, respectively. The sulfated polysaccharides extracted from Picochlorum sp. showed a strong DPPH scavenging effect with $85 \%$ antioxidant activity. The sulfated polysaccharides of Chlorella sorokiniana, Chlorella sp. $\left(\mathrm{L}_{2}\right)$ and Chlorella sp. $\left(\mathrm{D}_{1}\right)$ scavenged more than $90 \%$ of the ABTS radicals. However, the sulfated polysaccharide extracted from Chlorella sorokiniana, and Chlorella sp. (N4) showed anticoagulant properties. The dual anticoagulant-antioxidant activities in Chlorella sorokiniana could be explained by the combination of various factors including sulfate content and their binding site, monosaccharide residue and glycoside bond which are involved in the polysaccharide's bioactivity.
\end{abstract}

\section{Keypoints}

- Sulfated exopolysaccharides (sPS) were extracted from marine green microalgae by the heated acid extraction method.

- sPS with the higher sulfate/sugar ratio presented potent ABTS radical scavenging activity.

- Some of the sPS revealed anticoagulant effects in activated partial thromboplastin time (aPTT) and prothrombin time (PT) assays.

Keywords: Marine microalgae, Sulfated exopolysaccharide, Anticoagulant, Antioxidant

\section{Introduction}

There is a remarkable focus on the development of value-added functional food products with healthpromoting properties and improved nutrition from the new natural marine resources (Galasso et al. 2019; Bernaerts et al. 2019). The wide diversity in the biochemical

\footnotetext{
*Correspondence: m.safavi@irost.ir; mirdamadi@irost.ir Department of Biotechnology, Iranian Research Organization for Science and Technology (IROST), P. O. Box 3353-5111, Tehran, Iran
}

composition of marine organisms represents a rich source of valuable metabolites. Marine valuable bioactive compounds such as microalgae exopolysaccharides (EPS) are known as novel and interesting resources for the pharmaceutical and food industry (Liu et al. 2018; Zhang et al. 2019). The various biological activity of EPS is due to a complex interaction of multiple structural patterns including molecular weight, the sugar residue composition, types of glycosidic bonds, the monosaccharides nature, and the presence of some 
non-sugar units (sulfates, methyl, organic acid, amino acids, or amine) in the polysaccharide backbone (Berthon et al. 2017; Pierre et al. 2019). Certainly, the most common structural pattern of EPS consists of sulfate esters attached to glycosides and their sulfation level play an important role in biological applications (Zhang et al. 2019). Sulfate content between the sulfated polysaccharides (sPS) extracted from the various strains of microalgae are different (De Jesus Raposo et al. 2013). The content of sulfate sPS has a strong effect on physiochemical characterization and biological activity (Zhang et al. 2019; Jiao et al. 2011).

Recently, the importance of microalgal sPS in cosmetics, food, medical and pharmacological industries has grown significantly (Zhang et al. 2019; Minhas et al. 2016). They have shown antibacterial, antiviral (De Jesus Raposo et al. 2013; Wu et al. 2013), anti-inflammatory (Wu et al. 2015), antioxidant, anti-tumor and lowering cholesterol activities (Bernaerts et al. 2019; Barkia et al. 2019; Amaro et al. 2013). They are used to block the adhesion of pathogenic microorganisms such as Helicobacter pylori on epithelial cells as an anti-adhesive agent (Guzman-Murillo and Ascencio 2000; Ascencio et al. 1993).

The pharmaceutical and food industries have shown rapid interest in the development of natural, safe and new multi-target bioactive compounds like antioxidants and anticoagulants especially of marine origin (Chu 2011; Burg and Oshrat 2015). Marine algal sPS possess potent antioxidant activities through scavenging effects on the free radicals with direct or indirect interaction. In the continuing search for new and natural resources of bioactive compounds for anticoagulant activity, microalgae sulfated polysaccharides with hemi-ester sulfate group in sugar units have been introduced. Algal sPS have an anticoagulant activity similar to heparin as a natural highly sulfated mucopolysaccharide (Mišurcová et al. 2015).

The anionic nature of sPS due to the existence of the sulfate group makes them suitable candidates for bioapplications such as antioxidant and anticoagulant agents. Microalgae sPS as a glycosaminoglycan containing sulfate ester in their various sugar units can be an interesting candidate for medical applications (Marques et al. 2016).

In the present study, the sPS production and characterization in terms of yield, total carbohydrate and sulfate contents of the five isolated microalgae strains from the Persian Gulf are described. Upon our knowledge, this study represents the first description of isolated microalgal strains [Chlorella sorokiniana, Chlorella sp. $\left(\mathrm{L}_{2}\right)$, Chlorella sp. $\left(\mathrm{D}_{1}\right)$, Chlorella sp. $\left(\mathrm{N}_{4}\right)$ and Picochlorum sp.] from these habitats for sPS production. The strains containing the sPS with the most potent antioxidant and anticoagulant activities have been evaluated and presented.

\section{Material and method Material and chemical}

Sodium nitrate, calcium chloride dehydrates, magnesium sulfate heptahydrate, potassium phosphate, monopotassium phosphate, sodium chloride, boric acid, EDTA, zinc sulfate heptahydrate, chloride tetrahydrate, molybdenum trioxide, copper (II) sulfate pentahydrate and cobalt (II) nitrate hexahydrate were obtained from Sigma-Aldrich, Dorset, UK. 2,2'-azino-bis(3-ethylbenzthiazoline-6-sulfonate) (ABTS), 1,1-diphenyl-2 picrylhydrazyl (DPPH), were purchased from Sigma Chemical Co. (St. Louis, MO, USA). Commercial kits for aPTT and PT tests were purchased from Fisher Scientific, Canada. Heparin sodium was obtained from Hi-Media Laboratories, Mumbai, India.

\section{Cultivation of microalgal strain}

Five microalgae strains $\left(\mathrm{L}_{1}, \mathrm{~N}_{4}, \mathrm{D}_{1}, \mathrm{~L}_{2}, \mathrm{~S}_{1}\right)$ used in this study were isolated from the Persian Gulf and the Qeshm Island $\left(26^{\circ} 32 \mathrm{~N}, 53^{\circ} 56 \mathrm{E}\right)$, at the southern of Iran and deposited in Persian Type Culture Collection (PTCC) as NO. M8011, M8013, M8010, M8012, M6032, respectively. The microalgae strains were cultured in Erlenmeyer flasks with the BBM medium. BBM stock solutions (per liter) contain 25 g sodium nitrate $\left(\mathrm{NaNO}_{3}\right)$; $2.5 \mathrm{~g}$ calcium chloride dehydrate, $\left(\mathrm{CaCl}_{2} \cdot 2 \mathrm{H}_{2} \mathrm{O}\right) ; 7.5 \mathrm{~g}$ magnesium sulfate heptahydrate $\left(\mathrm{MgSO}_{4} .7 \mathrm{H}_{2} \mathrm{O}\right) ; 7.5 \mathrm{~g}$ potassium phosphate $\left(\mathrm{K}_{2} \mathrm{HPO}_{4}\right) ; 17.5 \mathrm{~g}$ monopotassium phosphate $\left(\mathrm{KH}_{2} \mathrm{PO}_{4}\right) ; 2.5 \mathrm{~g}$ sodium chloride $(\mathrm{NaCl})$; $11.42 \mathrm{~g}$ boric acid $\left(\mathrm{H}_{3} \mathrm{BO}_{3}\right)$; alkaline EDTA solution, acidified iron solution; trace metal solution containing $8.82 \mathrm{~g}$ zinc sulfate heptahydrate $\left(\mathrm{ZnSO}_{4} .7 \mathrm{H}_{2} \mathrm{O}\right) ; 1.44 \mathrm{~g}$ manganese (II) chloride tetrahydrate $\left(\mathrm{MnCl}_{2} \cdot 4 \mathrm{H}_{2} \mathrm{O}\right) ; 0.71 \mathrm{~g}$ molybdenum trioxide $\left(\mathrm{MoO}_{3}\right) ; 1.57 \mathrm{~g}$ copper (II) sulfate pentahydrate $\left(\mathrm{CuSO}_{4} \cdot 5 \mathrm{H}_{2} \mathrm{O}\right)$; and $0.49 \mathrm{~g}$ cobalt (II) nitrate hexahydrate $\left(\mathrm{Co}\left(\mathrm{NO}_{3}\right) 2.6 \mathrm{H}_{2} \mathrm{O}\right)$ (Bold 1949). Cultures were incubated under fluorescent lamps illumination in a 12/12 dark/light cycle, at an irradiance level of $70 \mathrm{~mol}$ photons $\mathrm{m}^{-2} \mathrm{~s}^{-1}$ and room temperature. To monitor cell growth and quantify the different microalgae biomass calculation, cell density was measured by counting using a hemocytometer and a light microscope. Optical density was measured by the absorbance using a UV-Visible spectrophotometer (BioTek, Epoch, Gen5) at the wavelength of $600-680 \mathrm{~nm}$. To calculate the dry weight of the samples (biomass per volume of culture $(\mathrm{g} / \mathrm{L})$, samples were centrifuged at $8000 \times g, 10 \mathrm{~min}$ and the biomass cake was dried at $60^{\circ} \mathrm{C}$ overnight. 


\section{Morphological and molecular characterization}

During the culturing process capsule's microalgae were identified by observation of morphological characteristics under a light microscope with negative staining. After elementary identification, the molecular analysis was further confirmed by sequencing of the $18 \mathrm{~S}$ ribosomal RNA gene.

\section{sPS extraction}

Dried microalgae's powder was subjected to acidic hydrolysis using hydrochloric acid $(0.07 \%)$ at $90{ }^{\circ} \mathrm{C}$ for $4 \mathrm{~h}$. After hydrolysis, the mixture was centrifuged $\left(10,000 \times g, 10 \mathrm{~min}, 4{ }^{\circ} \mathrm{C}\right)$ and then the supernatant was precipitated with $95 \%$ ethanol $(1: 1)(\mathrm{v} / \mathrm{v})$ with mechanical stirring and kept at $4{ }^{\circ} \mathrm{C}$ overnight. To obtain the polysaccharide-enriched fraction, the mixture was centrifuged $\left(10,000 \times g, 10 \mathrm{~min}, 4{ }^{\circ} \mathrm{C}\right)$, collected, lyophilized, and stored at $4{ }^{\circ} \mathrm{C}$ for further study. The sPS extraction yield (\%) was calculated as follows (Ale et al. 2012):

$$
\text { sPS extraction yield }(\%)=\text { Dried crude sPS weight }(\mathrm{g})
$$

$$
\text { /Powder weight }(\mathrm{g}) \times 100 \%
$$

\section{Determination of sPS total carbohydrates}

Total carbohydrates of EPS were analyzed by the phenolsulfuric acid method as described by Dubois et al. (1956). It is based on the production of furfural derivatives due to the dehydration of hydrolyzed saccharides with concentrated sulfuric acid. Thereafter, 5\% phenol was added to the solution and incubated in the water bath for $10 \mathrm{~min}$ at $90{ }^{\circ} \mathrm{C}$. After cooling to room temperature, the plate was read using a UV-Visible spectrophotometer (BioTek, Epoch, Gen5) at $490 \mathrm{~nm}$. The calibration curve was created using known concentrations of D-glucose $(0-0.2 \mathrm{mg} / \mathrm{mL})$ and heparin sodium stock solution $(0-5 \mathrm{mg} / \mathrm{mL})$ as a reference standard.

\section{Determination of sPS sulfate content}

The sulfate content measurement was carried out according to a $\mathrm{BaCl}_{2}$ gelatin method with some modifications (Dodgson and Price 1962). Briefly, the samples were hydrolysis in $\mathrm{N}$-hydrochloric acid $1 \mathrm{M}$ at $105-110{ }^{\circ} \mathrm{C}$ for $5 \mathrm{~h}$. Then, $3 \%(\mathrm{w} / \mathrm{v})$ trichloroacetic acid and barium chloride-gelatin reagent were added to the mixture, which was kept for 15-20 min at room temperature. The solution absorbance was measured at $360 \mathrm{~nm}$ (BioTek, Epoch, Gen5). The calibration curve was obtained using $\mathrm{K}_{2} \mathrm{SO}_{4}$ as a standard $(55-550 \mu \mathrm{g} / \mathrm{mL})$.

\section{HPLC and infrared spectroscopic analysis of sPS}

The samples were hydrolyzed in $0.07 \% \mathrm{HCl}$ for $4 \mathrm{~h}$ in $90{ }^{\circ} \mathrm{C}$. The monosaccharides in the microalgae extract were quantified by HPLC on Eurokat $\mathrm{H}$ column $(8 \mathrm{~mm} \times 30 \mathrm{~cm})$, using sulfuric acid $0.01 \mathrm{~N}(\mathrm{pH}: 2.15)$ as the mobile phase (flow rate $0.6 \mathrm{~mL} / \mathrm{min}$ ) and refractive index detector, as described by Dokhani et al. (1988). The IR spectra of the microalgae extracts samples were recorded on Bruker Tensor 27 FTIR spectrometer between 400 and $4000 \mathrm{~cm}^{-1}$ (Baky et al. 2013).

\section{Antioxidant activity DPPH radical scavenging assay}

The 2, 2 diphenyl-1-picrylhydrazyl (DPPH) radicals were used to investigate the scavenging activity of sPS. The assay was carried out in a 96 well microplate with $200 \mu \mathrm{L}$ of DPPH ( $2 \mathrm{Mm}$ at ethanol) solution and sample. Different concentrations $(0.5-2 \mathrm{mg} / \mathrm{mL})$ were tested for each sample in triplicate. The plate was then covered and kept for $30 \mathrm{~min}$ in the dark at room temperature and then absorbance was read at $517 \mathrm{~nm}$ using a microplate reader (BioTek, Epoch, Gen5). The percentage of DPPH scavenging activity was calculated (Romano et al. 2009).

\section{ABTS radical cation scavenging assay}

The capability of sPS scavenging activities of 2,20-azino-bis (3-ethylbenzothiazoline-6-sulphonic acid) (ABTS) radical cation was determined with the method reported by Liu et al. with some modifications. After preparation of ABTS solution (absorbance: $0.7 \pm 0.05$ at $734 \mathrm{~nm}$ ), the samples solutions $(2,1,0.5$, 0.1 , and $0.05 \mathrm{mg} / \mathrm{mL}$ ) were mixed with ABTS diluent. Then this mixture was kept in dark at room temperature for $6 \mathrm{~min}$ and the absorbance was measured at $734 \mathrm{~nm}$ in a microplate reader (BioTek, Epoch, Gen5). The scavenging rate (\%) was used to evaluate the ABTS scavenging capacity of different sPS (Liu et al. 2016).

\section{Anticoagulant activity}

Anticoagulant activities of EPS samples were evaluated using prothrombin time (PT) and activated partial thromboplastin time (APPT) assay. Control plasma samples were mixed with various EPS concentrations $(0.05-2 \mathrm{mg} / \mathrm{mL})$ and incubated at $37{ }^{\circ} \mathrm{C}$ for $60 \mathrm{~s}$. The mixture and pre-warmed aPTT assay reagent were incubated at $37{ }^{\circ} \mathrm{C}$ for $2 \mathrm{~min}$. Finally, pre-warmed 
calcium chloride $(0.25 \mathrm{~mol} / \mathrm{L})$ was added and clotting time was recorded. In prothrombin time (PT) assay, control plasma was mixed with EPS samples in different concentrations $(0.025-0.2 \mathrm{mg} / \mathrm{mL})$. Then prewarmed PT assay reagent was added and clotting time was recorded ( $\mathrm{Li}$ et al. 2016). The heparin was used as standard (0-0.05 mg/mL).

\section{Statistical analysis}

The carbohydrate and sulfate content data for microalgal strains were performed using a one-way analysis of variance (ANOVA, $\mathrm{p}<0.05$ ) with applying the Minitab 18 software. Another statistical analysis was carried out using excel 2019. All experiments were performed at least in triplicate and data were represented as mean \pm standard deviation.

\section{Result}

\section{Microalgae growth monitoring}

The microalgae growth was determined by optical density, cell counting and dry weight. The exponential and linear phases of growth occurred between 12 and 16th day. The highest growth percentage was observed at the exponential phase and then the growth decreases. The cultivation process was monitored up to 28 days and the stationary phase of isolated microalgae occurred between the 16 th and 28 nd day (Fig. 1). The cultivation period has been extended till 28 days because EPS is produced in the stationary phase.

\section{Microalgae morphological and molecular characterization} Morphological characters such as the presence of mucilaginous capsules surrounding microalgae cells were observed using light microscopy. The isolated microalgae were identified based on molecular studies using $18 \mathrm{~S}$ rRNA analysis to phylogenetically identify EPS-producing microalgae strains. The partial sequences of the $18 \mathrm{~S}$ rRNA gene of $\mathrm{L}_{1}, \mathrm{~N}_{4}, \mathrm{D}_{1}$, and $\mathrm{L}_{2}(816 \mathrm{bp}, 850 \mathrm{bp}, 980 \mathrm{bp}$ and $1216 \mathrm{bp}$ ) were submitted to GenBank, respectively. The result of the BLAST analysis of the rRNA sequence was shown in Table1.

\section{Carbohydrate and sulfate estimation}

As presented in Fig. 2, C. sorokiniana and Chlorella sp. $\left(L_{2}\right)$ showed the highest carbohydrate production. In this study yields of crude EPS produced by the microalgae strains ranged from 14 to $19 \%(\mathrm{w} / \mathrm{w})$ using heated acid in 4 h at $90^{\circ} \mathrm{C}$.

The carbohydrate contents in the EPSs were also found to vary greatly, ranging from $67 \mathrm{mg} / \mathrm{g}$ dry mass of Picochlorum sp. strain to $103 \mathrm{mg} / \mathrm{g}$ dry mass of Chlorella sp. $\left(\mathrm{N}_{4}\right)$ strain. Data in Fig. 3(A) shown that Chlorella sp. $\left(N_{4}\right)$ and $C$. sorokiniana produced higher carbohydrate content compared to other strains. Although Chlorella sp. $\left(N_{4}\right)$ had a low crude EPS extract but possess higher

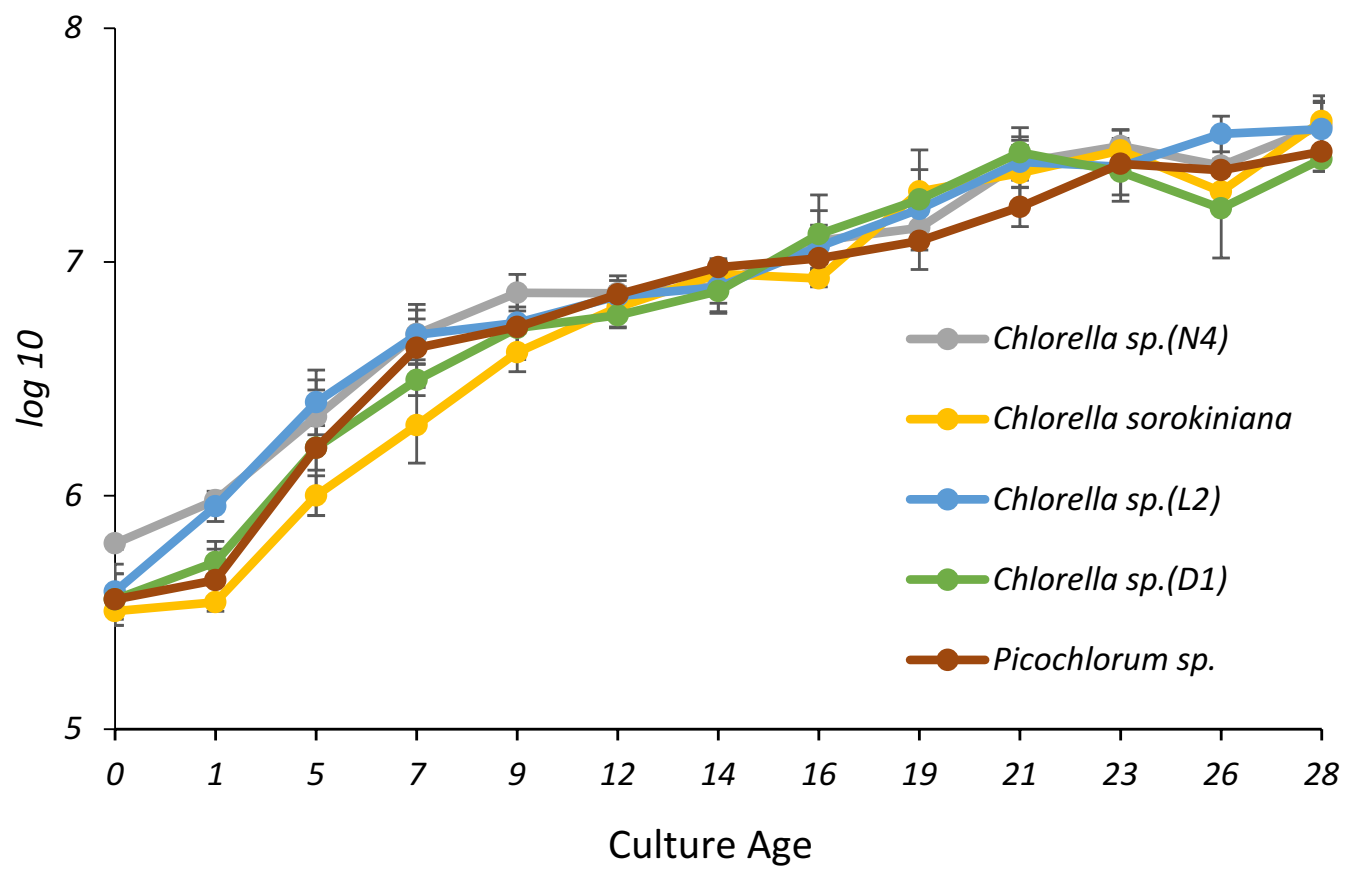

Fig. 1 Comparison of cell density growth profile from different algal strains grown in BBM media 


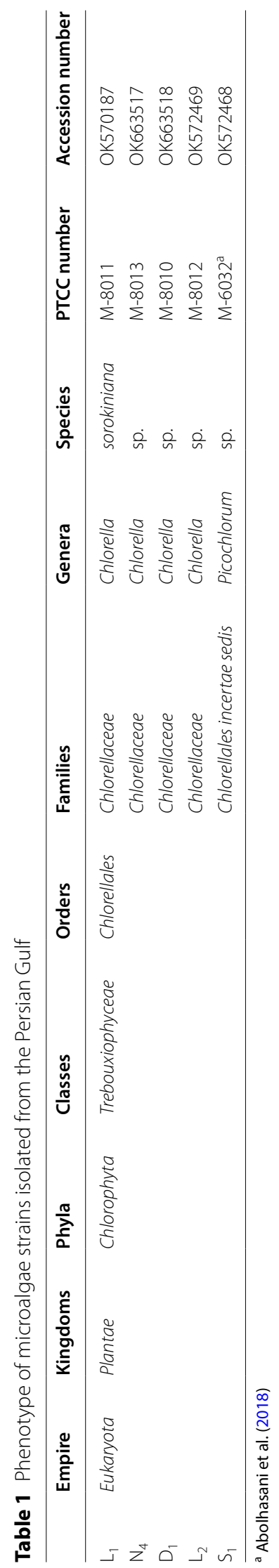




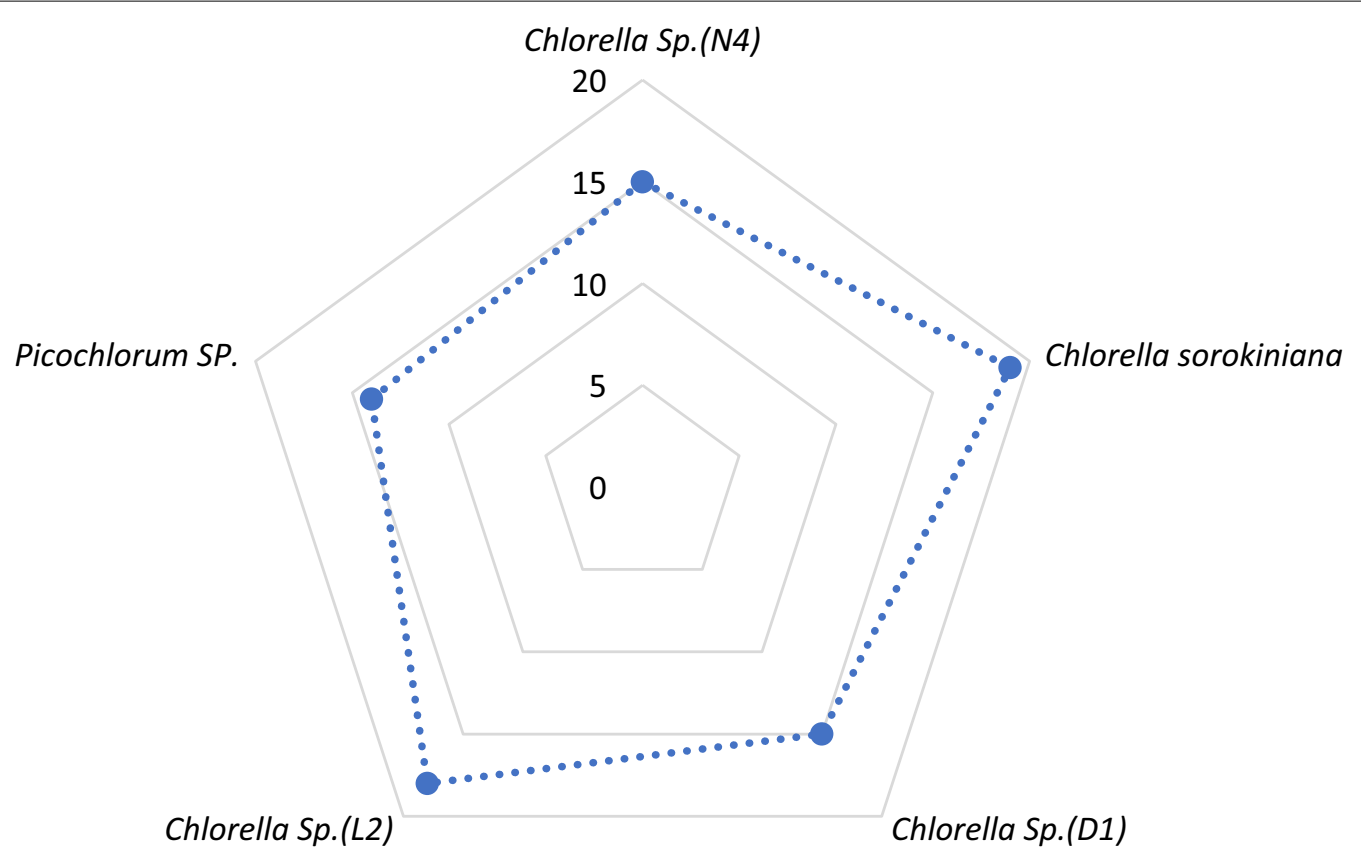

Fig. 2 Microalgae extract yield percentage

content of the EPS sugar (103 mg/g dry extract) as compared to $95 \mathrm{mg} / \mathrm{g}$ dry mass of C. sorokiniana.

In all the studied species, the EPSs with different sulfate contents were obtained ranging from about $35 \mathrm{mg} / \mathrm{g}$ dry biomass produced by Picochlorum sp. to about $93 \mathrm{mg} / \mathrm{g}$ dry biomass produced by C. sorokiniana (Fig. 3).

As shown in Fig. 4, the highest sulfate content of sPS from C. sorokiniana, and Chlorella sp. $\left(D_{1}\right)$ were reported to 93 and $76 \mathrm{mg} / \mathrm{g}$ dry mass, respectively.

Also, in this study carbohydrate and sulfate content of the algal extract were evaluated and compared with heparin sodium, as standard. A comparative data for total carbohydrate and sulfate content was presented in Table2.

In this respect, Chlorella sp. $\left(N_{4}\right)$ and C. sorokiniana with $768 \pm 18$ and $709 \pm 50$ carbohydrate content equivalent heparin sugar $\mathrm{mg} / \mathrm{g}$ dry biomass, presented the highest sugar content. But C. sorokiniana and Chlorella sp. $\left(D_{1}\right)$ contained more equivalent heparin sulfate. For example, the carbohydrate content in $1 \mathrm{~g}$ of $C$. sorokiniana dry extract was equivalent to $0.7 \mathrm{~g}$ heparin sugars content. According to the results, the sugar content of heparin equivalent in sulfated polysaccharides extracted from the studied strains was estimated to be $50-77 \%$ (Table 2). The sugar content of sPS was measured also using D-glucose as standard.
Fourier transform infrared (FT-IR) characterization and monosaccharide composition of the SPS

The FTIR spectra characters of polysaccharides and heparin sodium as standard was presented in Fig. 5. A total of 11 monosaccharides (mannose, glucosamine, trehalose, glucose, galactose, xylose, fructose and ribose) and oligosaccharides (sucrose, maltose and raffinose) were used as standard. The HPLC chromatogram of the crude sPS exhibited in Table 3.

\section{Radical scavenging activities}

The DPPH and ABTS colorimetric methods were used to assess the possible antioxidant potential of sPS. The scavenging DPPH radical's activity of sPS was determined. As shown in Fig. 6 some sulfated polysaccharides samples revealed apparent inhibition activities on DPPH radicals. Our results exhibited that the DPPH scavenging activity of Picochlorum sp. sulfated polysaccharides was significantly higher than other extracted polysaccharides $(\mathrm{p}<0.05)$.

The ABTS radical scavenging activities of sPS extracted from five microalgae strains at different concentrations $(0.05-2 \mathrm{mg} / \mathrm{mL}$ ) were evaluated (Fig. 7). The ABTS radical scavenging of sPS of all strains except Chlorella sp. $\left(N_{4}\right)$ may be due to the least sulfate/sugar ratio, reached to higher than $50 \%$ activity at $1 \mathrm{mg} / \mathrm{mL}$. 


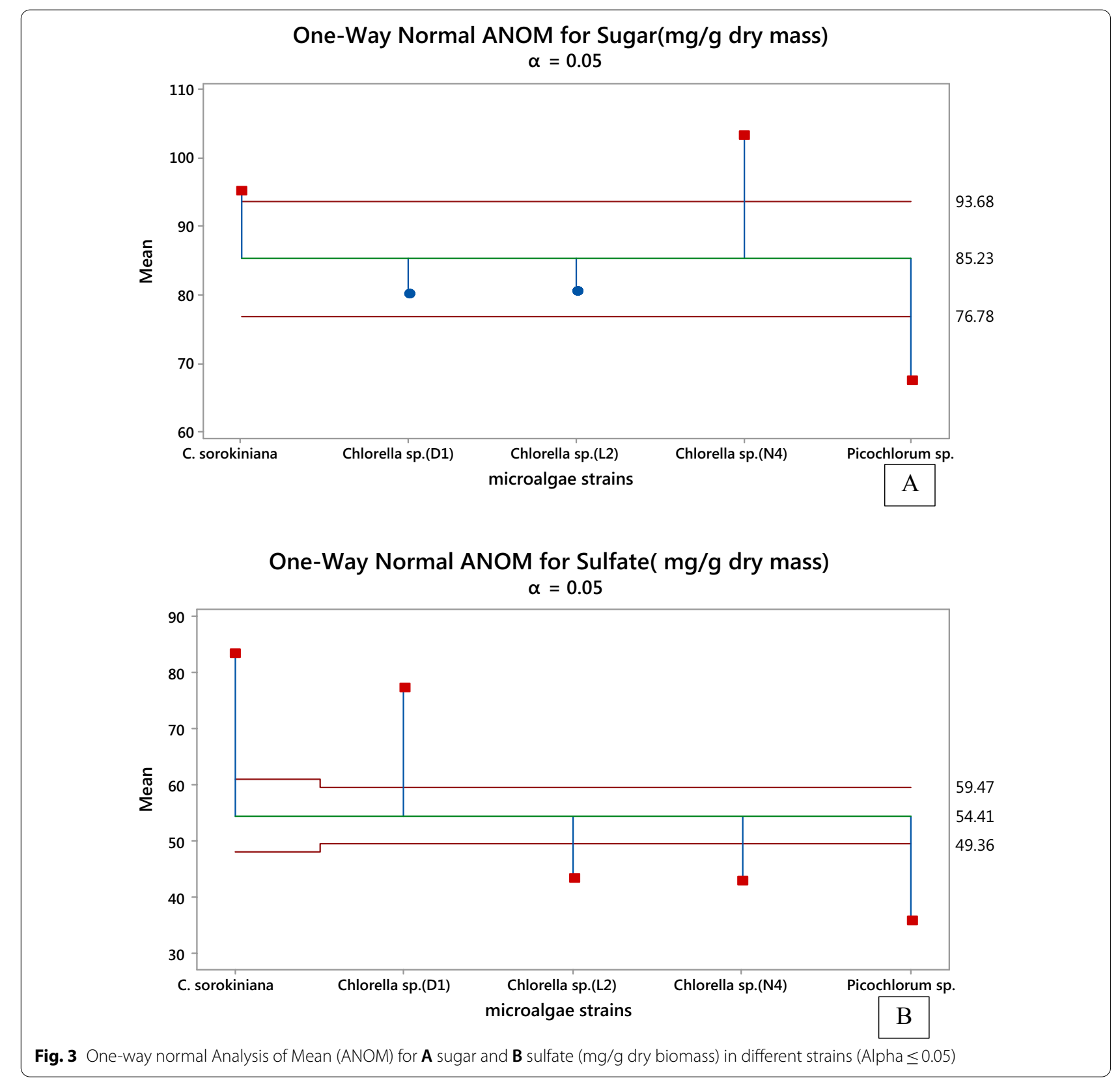

\section{Anticoagulant activities}

The anticoagulant activity of sPS and heparin as control were measured using PT and aPTT assay. As shown in Table 4, C. sorokiniana sPS prolonged clotting time more than $38 \mathrm{~s}$ at $10 \mu \mathrm{g} / \mathrm{mL}$ in aPTT test. The PT activity by C. sorokiniana and Chlorella sp. $\left(N_{4}\right) \mathrm{sPS}$ at $200 \mu \mathrm{g} / \mathrm{mL}$ increased clotting time (up to $14 \mathrm{~s}$ ).

sPS extracted from Chlorella sp. $\left(N_{4}\right)$ with the lowest sulfate/sugar ratio showed the highest PT activity, but despite high sulfate/sugar ratio in Chlorella sp. $\left(D_{1}\right)$ sPS, no anticoagulant activity was observed.

\section{Discussion}

Five microalgae strains isolated from the Persian Gulf were evaluated for biomass, polysaccharides production and their biological activities. The production of microalgal EPSs generally is related to the microalgae cultivation condition and is different from species to species (Delattre et al. 2016). Also, the extraction method has a significant effect on the extraction yields of microalgae polysaccharides (Yuan et al. 2020). According to our data the heated acid hydrolysis extraction method of Chlorella sp. polysaccharide yields ranged from 14 to $19 \%$ which is 


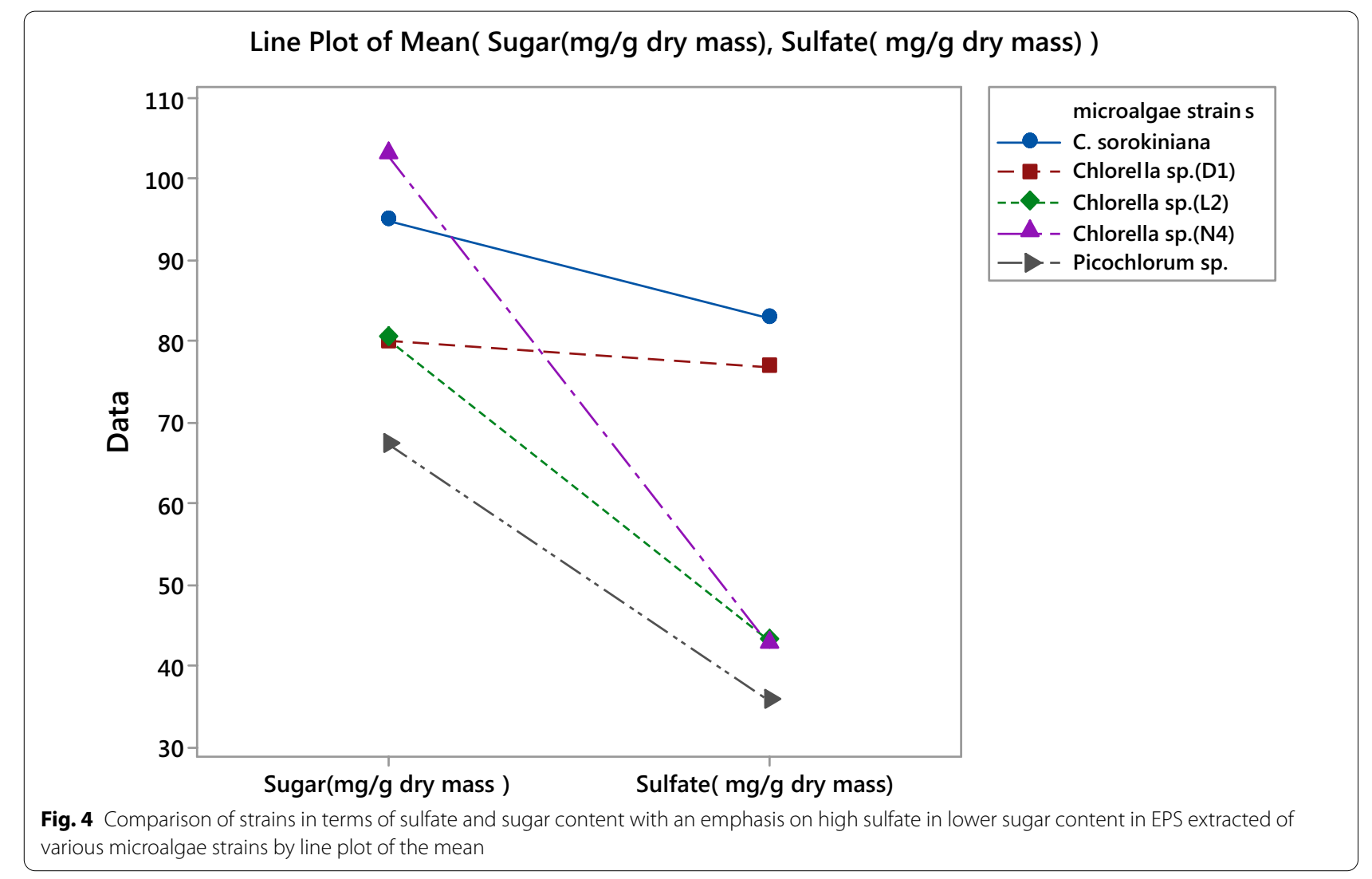

Table 2 Physio-chemical characteristics of biomass microalgae strains and EPS extracted by comparing heparin sodium and glucose standard (Value expressed as mean \pm SD)

\begin{tabular}{|c|c|c|c|c|c|c|c|c|}
\hline & Genus & $\begin{array}{l}\text { Weigh g/L } \\
\text { (dry mass) }\end{array}$ & $\begin{array}{l}\text { Yield (\%) of } \\
\text { extract from dry } \\
\text { microalgae }\end{array}$ & $\begin{array}{l}\text { Carbohydrate } \\
\text { Content (mg/g) } \\
\text { from crude } \\
\text { extract (Glucose } \\
\text { as standard) }\end{array}$ & $\begin{array}{l}\text { Sulfate ester } \\
\text { content }(\mathrm{mg} / \mathrm{g}) \\
\text { From crude } \\
\text { extract }\left(\mathrm{K}_{2} \mathrm{SO}_{4}\right. \\
\text { as standard })\end{array}$ & $\begin{array}{l}\text { Rate of } \\
\text { sulfate/ } \\
\text { sugar }\end{array}$ & $\begin{array}{l}\text { Carbohydrate } \\
\text { Content } \\
\text { (Equivalent } \\
\text { heparin } \\
\text { sugar }(\mathrm{mg}) / \mathrm{g} \text { dry } \\
\text { biomass }\end{array}$ & $\begin{array}{l}\text { Sulfate ester } \\
\text { content } \\
\text { (Equivalent } \\
\text { heparin } \\
\text { sulfate }(\mathrm{mg}) / \mathrm{g} \text { dry } \\
\text { biomass }\end{array}$ \\
\hline $\mathrm{N}_{4}$ & Chlorella sp. & 0.84 & $15 \pm 0.02$ & $103.12 \pm 2.52$ & $42.65 \pm 0.86$ & 0.41 & $768 \pm 18$ & $85 \pm 5$ \\
\hline $\mathrm{L}_{1}$ & $\begin{array}{l}\text { Chlorella soro- } \\
\text { kiniana }\end{array}$ & 0.51 & $19 \pm 0.05$ & $95.06 \pm 6.78$ & $93.73 \pm 5.95$ & 0.98 & $709 \pm 50$ & $338 \pm 36$ \\
\hline $\mathrm{L}_{2}$ & Chlorella sp. & 0.86 & $15 \pm 0.02$ & $80.54 \pm 1.66$ & $43.21 \pm 3.68$ & 0.53 & $600 \pm 12$ & $94 \pm 16$ \\
\hline $\mathrm{D}_{1}$ & Chlorella sp. & 0.59 & $18 \pm 0.05$ & $80.04 \pm 5.84$ & $76.95 \pm 2.35$ & 0.96 & $597 \pm 43$ & $245 \pm 14$ \\
\hline$S_{1}$ & Picochlorum sp. & 0.55 & $14 \pm 0.01$ & $67.40 \pm 7.31$ & $35.79 \pm 2.29$ & 0.53 & $502 \pm 54$ & $80 \pm 6$ \\
\hline
\end{tabular}

in agreement with that $(18 \%)$ of $80-90{ }^{\circ} \mathrm{C}$ water extraction method from the Chlorella source (Lai and Sun 2017). Also, Sui et al. (2012) study showed an extracted polysaccharide yield ranged from 13 to $19 \%$ from Chlorella sp. with hot water incubation $\left(90^{\circ} \mathrm{C}, 30 \mathrm{~min}\right)$. While the other study reported a crude polysaccharide yield of approximately $9.62 \pm 0.11 \%$ dry weight of Chlorella-Arc in the $88{ }^{\circ} \mathrm{C}$ and $3 \mathrm{~h}$ incubation (Song et al. 2018). The significant effect of the temperature on polysaccharide yield is related to the breaking of the internal and external hydrogen bonds of biopolymer and increasing the solubility of polysaccharides and their diffusion in water (Kumar and Fotedar 2009).

Likewise, the acid heated extraction EPS yield (19\%) for C. sorokiniana in this study remained higher than those obtained by Suárez et al. for the C. sorokiniana (15\%) by using hot water extraction (Suárez et al. 2005). The highest rate of sulfate/sugar, 0.98 and 0.96 were observed 

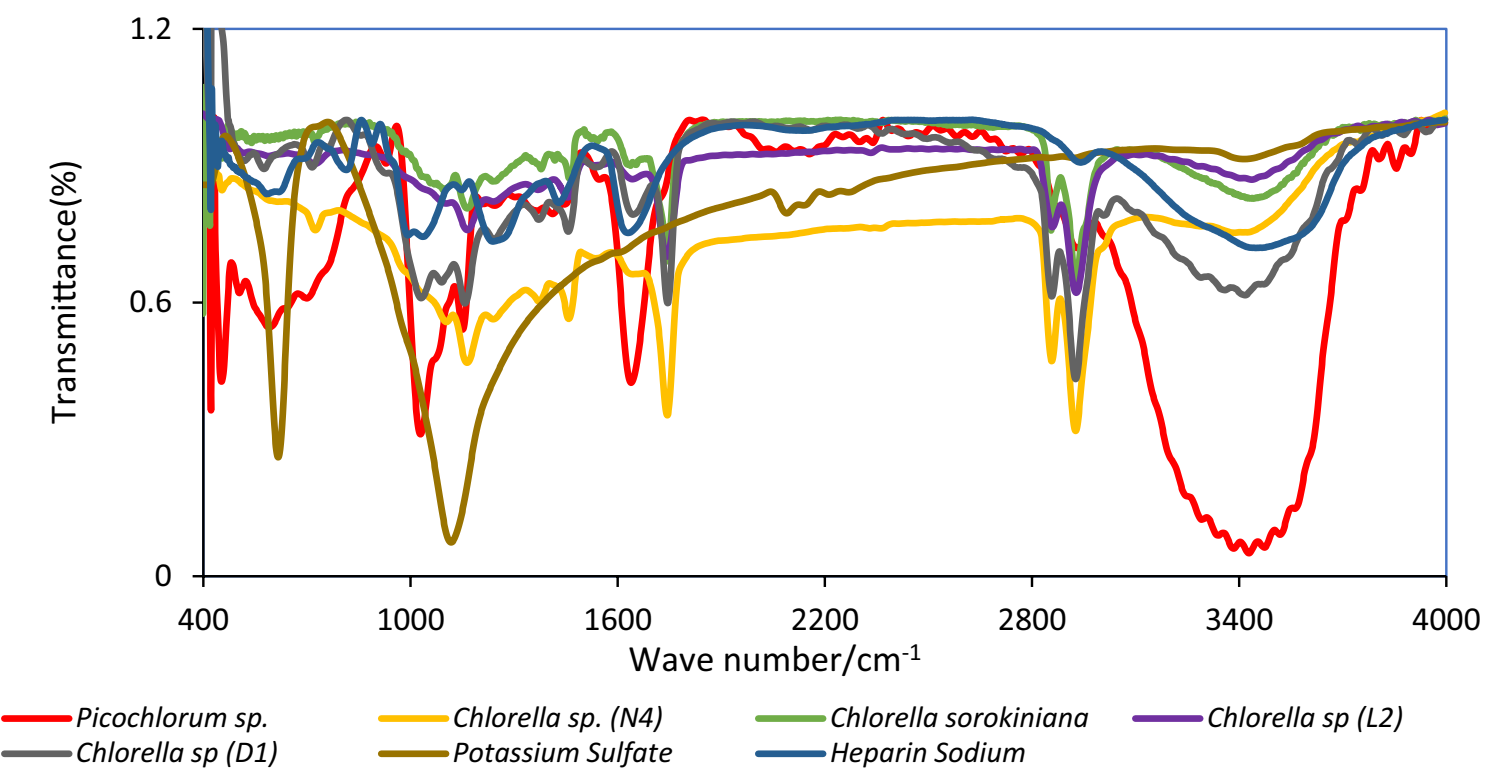

Chlorella sp (L2)

Fig. 5 FT-IR spectra of sPS extracted by comparing heparin and potassium sulfate as standard between 400 and $4000 \mathrm{~cm}^{-1}$

for C. sorokiniana and Chlorella sp. $\left(D_{1}\right)$, respectively (Table 2). But this ratio is slightly lower than El-Naggar et al. presented results (sulfate/sugar ratio:1.2) for Chlorella vulgaris polysaccharides extract (El-Naggar et al. 2020). Our findings were consistent with those obtained by Nishino and Nagumo who reported the sulfate/sugar ratios of macroalgae Ascophyllum nodosum and Fucus vesiculosus as 0.93 and 0.90 , respectively (Nishino and Nagumo 1992).

HPLC analysis of extracted EPS under $0.07 \%$ acid hydrolysis at $90{ }^{\circ} \mathrm{C}$ indicated that it is composed of different sugars in the form of monomer (glucose), dimer (sucrose), or trimer (raffinose). Sucrose was dominant in the sulfated polysaccharide extracted from C. sorokiniana acid hydrolysate. Glucosamine was the most abundant monosaccharide in the Chlorella sp. $\left(L_{2}\right)$ and Chlorella sp. $\left(N_{4}\right)$, respectively. Detection of amino sugar in Chlorella vulgaris cell wall was also reported previously by Ortiz-Tena et al. (2016). In addition, they revealed that detected glucosamine in microalgae is most probably part of chitin-like polymer available as $\mathrm{N}$-acetyl glucosamine in the cell wall (Ortiz-tena et al. 2016). In our study small amount of raffinose were observed in $C$. sorokiniana extracellular sugar. According to our knowledge, only one study reported accumulation of raffinose in unicellular Chlorella vulgaris after cold shock (Salerno and Pontis 1989). The culture condition and hydrolysis procedure including acid concentration, hydrolysis temperature and incubation time affect the microalgae monosaccharide's profile. The effect of culture conditions and polysaccharides hydrolysis procedure including acid concentration, temperature and incubation time, on the microalgae monosaccharides profile was confirmed previously (Schulze et al. 2017).

The absorbance at wavenumbers $3440 \mathrm{~cm}^{-1} \mathrm{OH}$ and $1200-800 \mathrm{~cm}^{-1}$ shows the IR spectrum of carbohydrates (McCann et al. 1992). The absorption band at around $3400-4450 \mathrm{~cm}^{-1}$, may be attributed to $\mathrm{O}-\mathrm{H}$ in C. sorokiniana, Chlorella sp. $\left(D_{1}\right)$, Chlorella sp. $\left(L_{2}\right)$ and Picochlorum sp. stretching and standard spectra of heparin sodium. The band at $2924 \mathrm{~cm}^{-1}$ was observed in C. sorokiniana, Chlorella sp. $\left(D_{1}\right)$ and heparin sodium was the characteristic peak of $\mathrm{C}-\mathrm{H}$ of the $\mathrm{CH}_{2}$ group. The band found at1440-1460 $\mathrm{cm}^{-1}$ was due to symmetric stretch vibration of $\mathrm{COO}-$ and $\mathrm{C}-\mathrm{O}$ within $\mathrm{COOH}$ in sPS from C. sorokiniana, Chlorella sp. $\left(N_{4}\right)$ and Chlorella sp. $\left(L_{2}\right)$. The peak at $1742 \mathrm{~cm}^{-1}$ is derived from ester carbonyl groups stretching band in Chlorella sp. $\left(D_{1}\right)$, C. sorokiniana, Chlorella sp. $\left(L_{2}\right)$ and Chlorella sp. $\left(N_{4}\right) .1641 \mathrm{~cm}^{-1}$, corresponding to the carbonyl group of a carboxylic acid group of uronic acid in Chlorella sp. $\left(L_{2}\right)$ and heparin sodium. The band at $1157 \mathrm{~cm}^{-1}$ is related to the $\mathrm{C}-\mathrm{O}$ stretch in phenolic compounds available in Chlorella sp. $\left(D_{1}\right)$. The peaks identified $1025 \mathrm{~cm}^{-1}$ in C. sorokiniana correspond to the $-\mathrm{CH}_{2} \mathrm{OH}$ groups and to the $\mathrm{C}-\mathrm{OH}$ stretching and bending of the $\mathrm{C}-\mathrm{OH}$ moiety of carbohydrates indicate a rich glycogen superficial layer. Carbohydrate FTIR analysis in this study was in agreement with that found by Dore et al. (2013), Guo et al. (2018), De Castro et al. (2018), Fernando et al. (2017), Lai and Sun (2017), Alvares et al. (2021) and Balan et al. (2019). The intense peak was found in all sPS extracted from all 


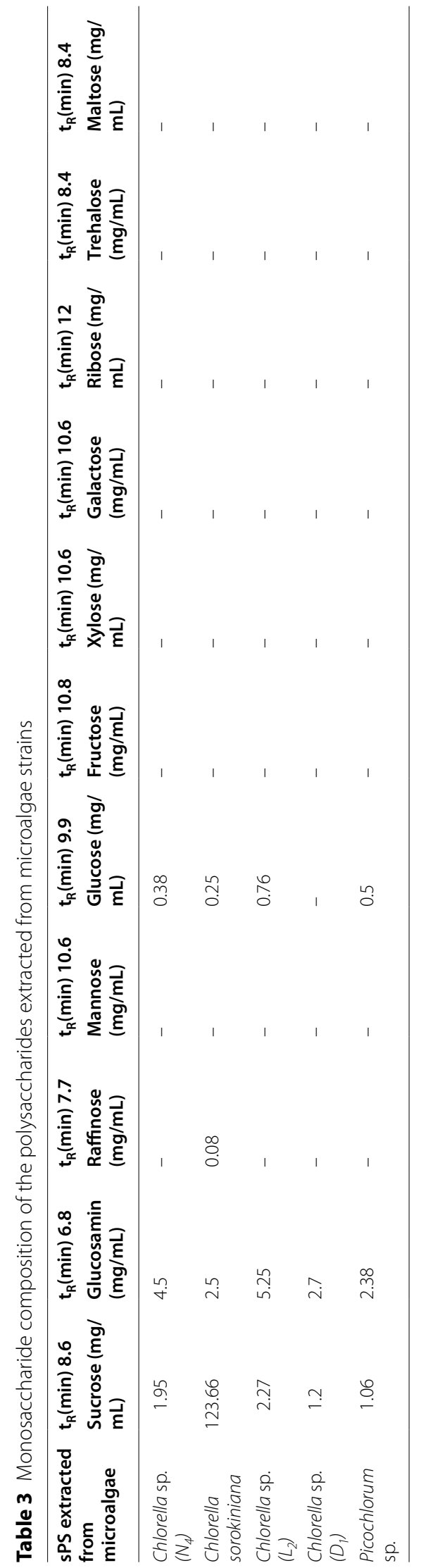




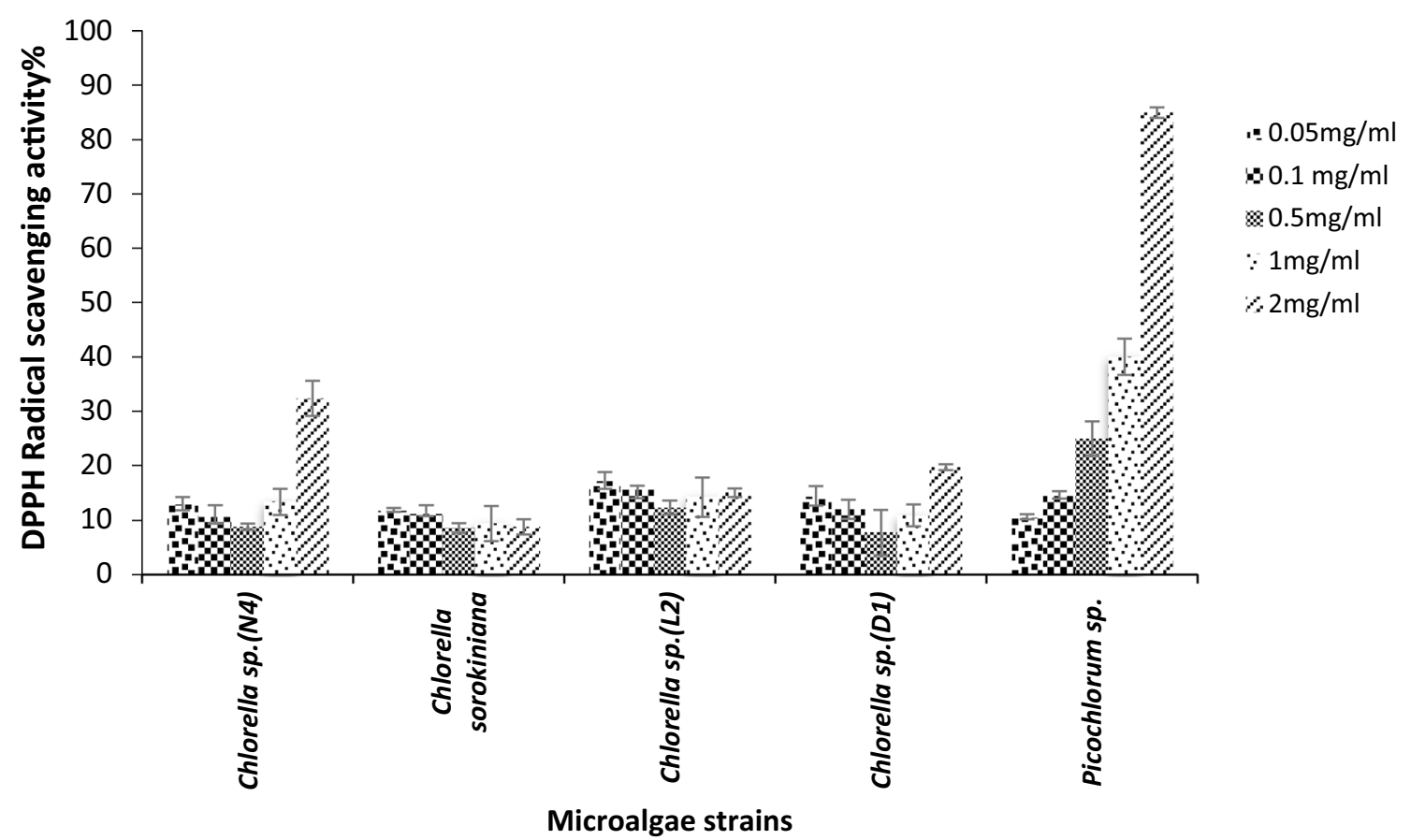

Fig. 6 Antioxidant activity, 1,1-diphenyl-2-picrylhydrazyl (DPPH) radicals scavenging activity by sPS extracted of various microalgae strains

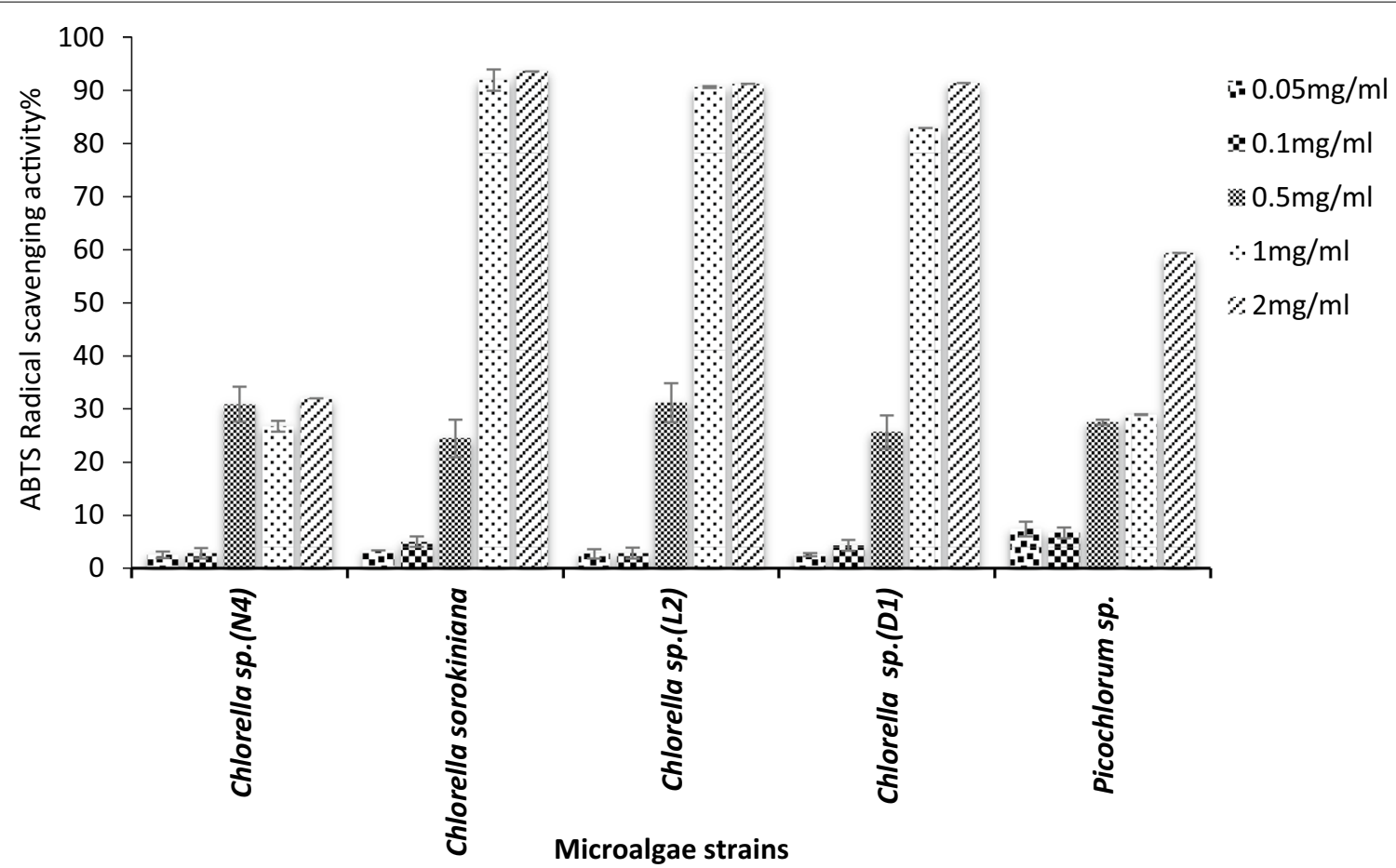

Fig. 7 Antioxidant activity, ABTS radicals scavenging activity by sPS extracted of various microalgae strains 
Table 4 Analysis of anticoagulant activity by aPTT and PT assay on Sps

\begin{tabular}{|c|c|c|c|c|c|c|}
\hline & $\mu \mathrm{g} / \mathrm{mL}$ & aPTT(s) & $\mathrm{T}_{1} / \mathrm{T}_{0}^{\mathrm{a}}$ & $\mu \mathrm{g} / \mathrm{mL}$ & $\mathrm{PT}(\mathrm{s})$ & $\mathrm{T}_{1} / \mathrm{T}_{0}^{\mathrm{a}}$ \\
\hline \multirow[t]{5}{*}{ Chlorella sp. $\left(\mathrm{N}_{4}\right)$} & 50 & $24.19 \pm 0.81$ & $0.71 \pm 0.03$ & 25 & $12.88 \pm 0.02$ & $0.98 \pm 0.008$ \\
\hline & 75 & $23.83 \pm 0.31$ & $0.70 \pm 0.009$ & 50 & $12.89 \pm 0.14$ & $0.98 \pm 0.005$ \\
\hline & 100 & $38.56 \pm 1.99$ & $1.18 \pm 0$ & 75 & $12.90 \pm 0.09$ & $0.99 \pm 0.003$ \\
\hline & 200 & $19.41 \pm 2.19$ & $0.57 \pm 00.01$ & 100 & $13.04 \pm 0.007$ & $1 \pm 0.0002$ \\
\hline & - & & - & 200 & $14.52 \pm 0.5$ & $1.11 \pm 0.01$ \\
\hline \multirow[t]{5}{*}{ Chlorella sorokiniana } & 50 & $26.79 \pm 1.28$ & $0.79 \pm 0.03$ & 25 & $11.90 \pm 0.28$ & $0.91 \pm 0.01$ \\
\hline & 75 & $23.08 \pm 0.55$ & $0.68 \pm 0.01$ & 50 & $12.96 \pm 0.07$ & $0.99 \pm 0.002$ \\
\hline & 100 & $35.83 \pm 1.06$ & $1.05 \pm 0.03$ & 75 & $13.3 \pm 0.82$ & $1.05 \pm 0.004$ \\
\hline & 200 & $32.56 \pm 2.19$ & $0.98 \pm 0.03$ & 100 & $13.01 \pm 0.04$ & $0.99 \pm 0.001$ \\
\hline & - & & - & 200 & $14.26 \pm 0.34$ & $1.09 \pm 0.01$ \\
\hline \multirow[t]{5}{*}{ Chlorella sp. $\left(L_{2}\right)$} & 50 & $23.41 \pm 0.94$ & $0.69 \pm 0.02$ & 25 & $11.88 \pm 0.16$ & $0.91 \pm 0.006$ \\
\hline & 75 & $16.53 \pm 1.45$ & $0.48 \pm 0.04$ & 50 & $12.91 \pm 0.09$ & $0.99 \pm 0.003$ \\
\hline & 100 & $36.78 \pm 1.24$ & $1.08 \pm 0.03$ & 75 & $12.54 \pm 0.23$ & $0.96 \pm 0.008$ \\
\hline & 200 & $18.65 \pm 0.55$ & $0.55 \pm 0.01$ & 100 & $13.56 \pm 0.27$ & $1.04 \pm 0.01$ \\
\hline & - & & - & 200 & $13 \pm 0.07$ & $0.99 \pm 0.002$ \\
\hline \multirow[t]{5}{*}{ Chlorella sp. $\left(D_{1}\right)$} & 50 & $19.69 \pm 0.01$ & $0.58 \pm 0.006$ & 25 & $12.45 \pm 0.44$ & $0.95 \pm 0.01$ \\
\hline & 75 & $27.89 \pm 0.43$ & $0.82 \pm 0.01$ & 50 & $13.75 \pm 0.54$ & $1.07 \pm 0.03$ \\
\hline & 100 & $32.05 \pm 1.20$ & $0.94 \pm 0.03$ & 75 & $12.70 \pm 0.36$ & $0.97 \pm 0.01$ \\
\hline & 200 & $33.74 \pm 0.68$ & $0.99 \pm 0.02$ & 100 & $13.43 \pm 0.08$ & $0.99 \pm 0.03$ \\
\hline & - & & - & 200 & $13.82 \pm 0.53$ & $1.06 \pm 0.02$ \\
\hline \multirow[t]{5}{*}{ Picochlorum sp. } & 50 & $31.69 \pm 1.87$ & $0.93 \pm 0.05$ & 25 & $12.36 \pm 0.11$ & $0.94 \pm 0.004$ \\
\hline & 75 & $21.3 \pm 1.20$ & $0.62 \pm 0.03$ & 50 & $11.26 \pm 0.53$ & $0.86 \pm 0.02$ \\
\hline & 100 & $25.07 \pm 0.47$ & $0.74 \pm 0.01$ & 75 & $12.85 \pm 0.21$ & $0.98 \pm 0.008$ \\
\hline & 200 & $21.49 \pm 0.51$ & $0.63 \pm 0.01$ & 100 & $12.62 \pm 0.49$ & $0.96 \pm 0.01$ \\
\hline & - & & - & 200 & $13.54 \pm 0.06$ & $1.03 \pm 0.022$ \\
\hline
\end{tabular}

HEP $5 \mu \mathrm{g} / \mathrm{mL}$; aPTT: $60.05 \pm 0.007 \mathrm{~s}$; Control: $33.87 \pm 0.45 \mathrm{~s}$ and HEP $25 \mu \mathrm{g} / \mathrm{mL}$; PT: $13.69 \pm 0.2 \mathrm{~s}$; Control: $13.03 \pm 0.2 \mathrm{~s}$. Data expressed as mean \pm standard deviation $(\mathrm{n}=3)$

${ }^{a}$ Clotting time in presence $\mathrm{SPS}\left(\mathrm{T}_{1}\right)$ and absence $\left(\mathrm{T}_{0}\right)$

microalgae except Picochlorum sp. at 1095-1164 $\mathrm{cm}^{-1}$, indicating stretching vibration of the $1070-1172 \mathrm{~cm}^{-1}$ in $\mathrm{K}_{2} \mathrm{SO}_{4}$ (Periasamy et al. 2009) and suggesting the presence of sulfate group.

The correlation of the polysaccharide structures with their biological function fulfilled the bioactivity of the exopolysaccharides produced by these strains. The maximum DPPH scavenging activities (85\%) were observed at the concentration of $2.0 \mathrm{mg} / \mathrm{mL}$ for Picochlorum sp. sPS. The hydrogen atom in the hydroxyl group available in Picochlorum sp. sPS (FTIR data) leads to the stronger hydrogen atom-donating capacity in DPPH scavenging assays. Many researchers have investigated the in vitro and in vivo antioxidant activities of microalgae polysaccharides. The 16-polysaccharide extracted from C. pyrenoidosa by $\mathrm{Hu}$ et al. (2007) displayed significant anti-radical activities, varying from $29.67 \pm 0.29 \%$ to $54.16 \pm 4.49 \%$ at $10 \mathrm{mg} / \mathrm{mL}$ ( $\mathrm{Hu}$ et al. 2007). In our study notable antioxidant activity was not observed in sPS extracted from microalgae C. sorokiniana (C. pyrenoidosa) at tested concentrations $(0.05-2 \mathrm{mg} / \mathrm{mL})$. Our finding was in keeping with many reports on the antioxidant activities of sPS extracted from algae. The evaluation of antioxidant activities of exopolysaccharides from Chlorella zofingiensis (EPS-CZ), C. vulgaris (EPS-CV) and $C$. pyrenoidosa (EPS-CP) demonstrated DPPH radical scavenging activities. At the concentration of $3.0 \mathrm{mg} /$ $\mathrm{mL}$, the EPS-CV and EPS-CZ inhibited $59.6 \%$ and $71.5 \%$ of DPPH radicals, respectively. The EPS-CP had $55.2 \%$ of $\mathrm{DPPH}$ radical scavenging activity at the concentration of $2.0 \mathrm{mg} / \mathrm{mL}$ (Zhang et al. 2019). According to Zhang et al. (2013) report water and alkali extracted polysaccharides from Enteromorpha linza showed over 83 and 89\% DPPH scavenging activity, respectively at $3.61 \mathrm{mg} / \mathrm{mL}$ concentration. The high DPPH scavenging activity, 73\%, at $160 \mu \mathrm{g} / \mathrm{mL}$ of extracted sPS from Gracilaria corticate and the $\mathrm{IC}_{50}$ value of $32 \mu \mathrm{g} / \mathrm{mL}$ for Nostoc carneum exopolysaccharide has been reported (Seedevi et al. 2016; Mervat et al. 2015). Also, the DPPH radical scavenging effect of crude polysaccharide from C. pyrenoidosa in concentration $10 \mathrm{mg} / \mathrm{mL}$ was reported as $54.16 \pm 4.49 \%$ ( Hu et al. 2007). The result of the present study indicated that due 
to the high electrons donating ability of sulfated polysaccharides of C. sorokiniana, Chlorella sp. $\left(L_{2}\right)$ and Chlorella sp. $\left(D_{1}\right)$, the ABTS radical scavenging activity was increased to $>82 \%$ at the concentration of $1 \mathrm{mg} / \mathrm{mL}$.

It is interesting to determine the chemical constituents and scavenging activity relationship for sPS extracted from microalgae. The sulfated polysaccharides from Chlorella sp. $\left(L_{2}\right)$ and Picochlorum sp. with similar sulfate/sugar ratio showed potent radical scavenging activities $91 \%$ in ABTS and $85 \%$ in DPPH scavenging activity, respectively.

The hypothesis of the relationship between the free radical scavenging capability of EPS and the existence of functional groups such as $\mathrm{C}=\mathrm{O},-\mathrm{COOH},-\mathrm{O}-$ and $-\mathrm{OH}$ in its structure due to donating electron activity is well accepted (Sun et al. 2015).

Based on the FTIR spectrum result, it is possible that high ABTS radical scavenging in C. sorokiniana, Chlorella sp. $\left(L_{2}\right)$ and Chlorella sp. $\left(D_{1}\right)$ sPS samples were due to the existence of the carbonyl group of a carboxylic acid group of uronic acid and the hydrogen atom in the hydroxyl group. Evaluating the results acquired for sPS extracted from four Chlorella species, sPS C. sorokiniana, Chlorella sp. $\left(D_{1}\right)$ and Chlorella sp. (L2) showed higher antioxidant activity than Chlorella sp. $\left(N_{4}\right)$. The sPS extracted from chlorella strains except for Chlorella sp. $\left(N_{4}\right)$ had relatively strong ABTS radical trapping, and the scavenging activity was $90 \%$ when the polysaccharide concentration was $2 \mathrm{mg} \mathrm{mL}^{-1}$. Since the electron transfer reaction in polysaccharides provides the hydrogen or electrons required to form stable molecules from free radicals (Wang et al. 2022). This result suggested that ABTS scavenging capacity may be due to the presence of the broad peak vibrations of the $\mathrm{OH}$ group (3200$3500 \mathrm{~cm}^{-1}$ ) in C. sorokiniana, Chlorella sp. $\left(D_{1}\right)$ and Chlorella sp. (L2). Low potency of the Chlorella sp. $\left(N_{4}\right)$ strain to inhibit free radicals was associated with the lack of this spectrum (FTIR spectrum data). Therefore since the ABTS assay evaluated non-physiological free radicals (Wang et al. 2022), it may be indicated sPS extracted from C. sorokiniana, Chlorella sp. $\left(D_{1}\right)$ and Chlorella sp. (L2) may directly scavenge free radicals.

ABTS scavenging activity of sPS extracted in the current study was higher than the scavenging activity of the previously reported study. According to Chen et al. (2018) study, the concentration of $4 \mathrm{mg} / \mathrm{mL}$ of AnPS polysaccharide fraction extracted from Ascophyllum nodosum had the highest ABTS radical scavenging activity (70\%) among three different fractions.

Antioxidant activity is related to the molecular weight, sulfate content and position of a sulfate group, different type of the major sugar unit, glycosidic branching and glycoprotein residuals of polysaccharides (Wang et al.
2013; Wang et al. 2018; Chu, 2011; Qi et al. 2005). There is a correlation between uronic acids, the reducing and nonreducing end contents and antioxidant activities in polysaccharides (Wang et al. 2013; Wang et al. 2018).

It was observed that aPTT and PT activity of C. sorokiniana and Chlorella sp. $\left(N_{4}\right)$ sPS were lower than heparin. Heparin quickly increased the aPTT and PT times; the clotting time was more than $60 \mathrm{~s}$ at $5 \mu \mathrm{g} / \mathrm{mL}$ for aPTT and $13.69 \mathrm{~s}$ at $25 \mu \mathrm{g} / \mathrm{mL}$ for PT. Therefore, position to obtain the same effect as with heparin high concentration of sPS were required. By our results, five times lower anticoagulant activity in aPTT assay was reported for sPS purified from Arthrospira platensis than heparin (Majdoub et al. 2009). Also, the anticoagulant activity of two sPS extracted from Monostroma nitidum was reported to be weaker than heparin (Mao et al. 2008).

According to some research, in addition to sulfate concentration, the differences in the structural variation of sPS such as the distribution pattern and position of sulfate and chemical composition mainly the monosaccharide units could affect the sPS anticoagulant activity ( $\mathrm{Li}$ et al. 2015; Yang et al. 2002; De Jesus Raposo et al. 2013). As can be seen from previous studies, the abundance of glucuronic acid branches in Cladosiphon okamuranus fucoidan, adversely affected the aPPT assay (Cumashi et al. 2007).

Conceptually, polysaccharides with in vitro low anticoagulant effects could be assumed as antithrombotic agents (Liet al. 2015; Mourão, 2015). In this regard, the tested sPS with poor anticoagulant activity may exhibit antithrombin activity in bleeding disorder which requires further study.

In total, the difference between the sulfate heteropolysaccharides extracted from the three chlorella strains in this study lies in their performance. For the anticoagulant effect, $C$. sorokiniana and Chlorella sp. $\left(N_{4}\right)$ showed higher activity than other chlorella strains. One explanation for this may be due to similar carbohydrate content equivalent heparin sugar $(\mathrm{mg}) / \mathrm{g}$ dry biomass in sPS extracted of C. sorokiniana and Chlorella sp. $\left(N_{4}\right)$. Moreover, the content of sulfate esters plays an important role in sPS bioactivities. Interestingly, Chlorella sp. $\left(N_{4}\right)$ with a lower sulfate/sugar ratio (0.41) showed lower antioxidant activity. Whereas Chlorella sp. (D1) with sulfate/sugar ratio 0.53 following C. sorokiniana and Chlorella sp. (L2) with sulfate/sugar ratios 0.98 and 0.94 , respectively, presented a high antioxidant effect. As a result, the finding of this study, suggest that antioxidant and anticoagulant activity of sPS was related to the sulfate ester content. This result indicates that some of the sPS could be a potential resource of natural antioxidants for further investigation in the food industry. So commercial development of this 
natural product can lead to the extension of functional food additives. Meanwhile, the C. sorokiniana sPS with anticoagulant and antioxidant activities could be a promising anticoagulant candidate with lower bleeding risk in stroke and heart ischemic disease.

\section{Abbreviations}

EPS: Exopolysaccharides; sPS: Sulfated polysaccharide; ABTS: 2,2'-Azino-bis(3ethylbenzthiazoline-6-sulfonate); DPPH: 1,1-Diphenyl-2 picrylhydrazyl; PT: Prothrombin time; APPT: Activated partial thromboplastin time.

\section{Acknowledgements}

This work has been supported by the Iranian Research Organization for Science and Technology (IROST).

\section{Authors' contributions}

ZM: conceptualization, investigation, methodology, validation, formal analysis, writing - original draft. MS: conceptualization, project administration, validation, review and editing. FA: resources, formal analysis. MH: visualization. SM: conceptualization, supervision, project administration, review and editing. All authors read and approved the final manuscript.

\section{Authors' information}

Zahra Mousavian: PhD student of Microbiology. Department of Biotech, IROST. Maliheh Safavi: Associate Professor of Biochemistry, Department of Biotech, IROST. Farzaneh Azizmohseni: Department of Biotechnology, Iranian Research Organization for Science and Technology (IROST). Mahnaz Hadizadeh: Associate Professor of Biochemistry, Department of Biotech, IROST. Saeed Mirdamadi: Professor of Medical Microbiology and Biotechnology. Department of Biotech, IROST.

\section{Funding}

This work has been supported by the World Academy of Sciences (Grant No. 14-393RG/PHA/AS_C-UNESCO FR: 3240283441.

\section{Availability of data and materials}

The data that support the findings of this study are available from the corresponding author upon reasonable request.

\section{Declarations}

Ethics approval and consent to participate:

Not applicable. This article does not contain any studies with human participants or animals performed by any of the authors.

\section{Consent for publication:}

Not applicable.

\section{Competing interests}

The authors declare that they have no known competing financial interests or personal relationships that could have appeared to influence the work reported in this paper.

Received: 19 October 2021 Accepted: 17 February 2022

Published online: 03 March 2022

\section{References}

Abolhasani MH, Safavi M, Goodarzi MT, Kassaee SM, Azin M (2018) Identification and anti-cancer activity in $2 \mathrm{D}$ and $3 \mathrm{D}$ cell culture evaluation of an Iranian isolated marine microalgae Picochlorum sp. RCC486. DARU J Pharm Sci 26:105-116. https://doi.org/10.1007/s40199-018-0213-5

Ale MT, Mikkelsen JD, Meyer AS (2012) Designed optimization of a singlestep extraction of fucose-containing sulfated polysaccharides from Sargassum sp. J Appl Phycol 24:715-723. https://doi.org/10.1007/ s10811-011-9690-3
Alvarez X, Alves A, Ribeiro MP, Lazzari M, Coutinho P, Otero A (2021) Biochemical characterization of Nostoc sp. exopolysaccharides and evaluation of potential use in wound healing. Carbohydr Polym 254:117303. https:// doi.org/10.1016/j.carbpol.2020.117303

Amaro HM, Barros R, Guedes AC, Malcata FX (2013) Microalgal compounds modulate carcinogenesis in the gastrointestinal tract. Trends Biotechnol 31:92-98. https://doi.org/10.1016/j.tibtech.2012.11.004

Ascencio F, Franssont LA, Wadstromf T (1993) Affinity of the gastric pathogen Helicobacter pylori for the $\mathrm{N}$-sulfated glycosaminoglycan heparin sulphate. J Med Microbiol 38:240-244

Baky AE, El Baz KF, H, EL-Latife (2013) Induction of sulfated polysaccharides in Spirulina platensis as response to nitrogen concentration and its biological evaluation. J Aquac Res Dev. https://doi.org/10.4172/2155-9546.10002 06

Balan V, Mihai CT, Cojocaru FD, Uritu CM, Dodi G, Botezat D, Gardikiotis I (2019) Vibrational spectroscopy fingerprinting in medicine: from molecular to clinical practice. Materials 12:1-40. https://doi.org/10.3390/ma12182884

Barkia I, Saari N, Manning SR (2019) Microalgae for high-value products towards human health and nutrition. Mar Drugs. https://doi.org/10.3390/ md17050304

Bernaerts TMM, Gheysen L, Foubert I, Hendrickx ME, Van Loey AM (2019) The potential of microalgae and their biopolymers as structuring ingredients in food: a review. Biotechnol Adv. https://doi.org/10.1016/j.biotechadv. 2019.107419

Berthon JY, Nachat-Kappes R, Bey M, Cadoret JP, Renimel I, Filaire E (2017) Marine algae as attractive source to skin care. Free Radical Res 51:555567. https://doi.org/10.1080/10715762.2017.1355550

Bold HC (1949) The morphology of Chlamydomonas chlamydogama, sp. Nov. Bull Torrey Bot Club 76:101-108

Burg A, Oshrat L (2015) Salt effect on the antioxidant activity of red microalgal sulfated polysaccharides in soy-bean formula. Mar Drugs 13:6425-6439. https://doi.org/10.3390/md13106425

Chen L, Wang Y, Yang H, Li H, Xu W, Chen G, Zhu H (2018) Physicochemical characterization, antioxidant and immunostimulatory activities of sulfated polysaccharides extracted from Ascophyllum nodosum. Molecules. https://doi.org/10.3390/molecules23081912

Chu W-L (2011) Potential applications of antioxidant compounds derived from algae. Curr Top Nutraceutical Res 9:83-98

Cumashi A, Natalia A, Piccoli A, Totani L, Tinari N, Morozevich E, Berman AE, Bilan MI, Usov Al, Ustyuzhanina NE, Grachev A, Sanderson CJ, Kelly M, Rabinovich A, lacobelli S (2007) A comparative study of the anti-inflammatory, anticoagulant, antiangiogenic and antiadhesive activities of nine different fucoidans from brown seaweeds. Glycobiology 17:541-552

De Castro JPL, Costa LEC, Pinheiro MP, Dos Santos FT, De Vasconcelos PHM, Funari LM, Daudt RM, Dos Santos GRC, Cardozo NSM, Freitas ALP (2018) Polysaccharides of red alga Gracilaria intermedia: Structure, antioxidant activity and rheological behavior. Polimeros 28:178-186. https://doi.org/ 10.1590/0104-1428.013116

de Jesus Raposo MF, Morais RMSC, Morais AMMB (2013) Bioactivity and applications of sulphated polysaccharides from marine microalgae. Mar Drugs 11:233-252. https://doi.org/10.3390/md11010233

Delattre C, Pierre G, Laroche C, Michaud P (2016) Production, extraction and characterization of microalgal and cyanobacterial exopolysaccharides. Biotechnol Adv 34:1159-1179. https://doi.org/10.1016/j.biotechadv.2016. 08.001

Dodgson KS, Price RG (1962) A note on the determination of the ester sulphate content of sulphated polysaccharides. Biochem J 84:106-110

Dokhani S, Qoraikul B, Palcic M, Hadziyev D (1988) High performance liquid chromatographic analysis of sugars in raw and processed potatoes. Iran Agric Res 7:23-36

Dore CMPG, Faustino Alves MGDC, Pofírio Will LSE, Costa TG, Sabry DA, De Souza Rêgo LAR, Accardo CM, Rocha HAO, Filgueira LGA, Leite EL (2013) A sulfated polysaccharide, fucans, isolated from brown algae Sargassum vulgare with anticoagulant, antithrombotic, antioxidant and anti-inflammatory effects. Carbohyd Polym 91:467-475. https://doi.org/10.1016/j. carbpol.2012.07.075

Dubois M, Gilles KA, Hamilton JK, Rebers PA, Smith F (1956) Colorimetric method for determination of sugars and related substances. Anal Chem 28:350-356 
El-Naggar NEA, Hussein MH, Shaaban-Dessuuki SA, Dalal SR (2020) Production, extraction and characterization of Chlorella vulgaris soluble polysaccharides and their applications in AgNPs biosynthesis and biostimulation of plant growth. Sci Rep 10:1-19. https://doi.org/10.1038/ s41598-020-59945-w

Fernando SIP, Sanjeewa AKK, Samarakoon KW, Lee WW, Kim HS, Kim EA, Gunasekara UK, Abeytunga DTU, Nanayakkara C, De Silva ED, Lee HS, Jeon YJ (2017) FTIR characterization and antioxidant activity of water soluble crude polysaccharides of Sri Lankan marine algae. Algae 32:75-86. https://doi.org/10.4490/algae.2017.32.12.1

Galasso C, Gentile A, Orefice I, lanora A, Bruno A, Noonan DM, Sansone C, Albini A, Brunet C (2019) Microalgal derivatives as potential nutraceutical and food supplements for human health: a focus on cancer prevention and interception. Nutrients. https://doi.org/10.3390/nu11061226

Guo Q, Ai L, Cui SW (2018) Fourier transform infrared spectroscopy (FTIR) for carbohydrate analysis. In: Guo Q, Ai L, Cui SW (eds) Methodology for structural analysis of polysaccharides. Springer, Berlin, pp 69-71

Guzman-Murillo MA, Ascencio F (2000) Anti-adhesive activity of sulphated exopolysaccharides of microalgae on attachment of red sore diseaseassociated bacteria and Helicobacter pylori to tissue culture cells. Lett Appl Microbiol 30:473-478. https://doi.org/10.1046/j.1472-765x.2000.00751.x

Hu Q, Pan B, Xu J, Sheng J, Shi Y (2007) Effects of supercritical carbon dioxide extraction conditions on yields and antioxidant activity of Chlorella pyrenoidosa extracts. J Food Eng 80:997-1001. https://doi.org/10.1016/j. jfoodeng.2006.06.026

Jiao G, Yu G, Zhang J, Ewart HS (2011) Chemical structures and bioactivities of sulfated polysaccharides from marine algae. Mar Drugs 9:196-233. https://doi.org/10.3390/md9020196

Kumar V, Fotedar R (2009) Agar extraction process for Gracilaria cliftonii (Withell, Millar, \& Kraft, 1994). Carbohyd Polym 78:813-819. https://doi. org/10.1016/j.carbpol.2009.07.001

Lai PF, Sun TC (2017) Optimizing extraction process and characterization of antioxidant ingredients from Chlorella sorokiniana. MOJ Food Process Technol 5:202-210. https://doi.org/10.15406/mojfpt.2017.05.00114

Li N, Mao W, Yan M, Liu X, Xia Z, Wang S, Xiao B, Chen C, Zhang L, Cao S (2015) Structural characterization and anticoagulant activity of a sulfated polysaccharide from the green alga Codium divaricatum. Carbohyd Polym 121:175-182. https://doi.org/10.1016/j.carbpol.2014.12.036

Li N, Liu X, He X, Wang S, Cao S, Xia Z, Xian H, QinMao LW (2016) Structure and anticoagulant property of a sulfated polysaccharide isolated from the green seaweed Monostroma angicava. Carbohyd Polym. https://doi.org/ 10.1016/j.carbpol.2016.12.013

Liu Y, Zhang B, Ibrahim SA, Gao S, Yang H, Huang W (2016) Purification, characterization and antioxidant activity of polysaccharides from Flammulina velutipes residue. Carbohyd Polym 145:71-77. https://doi.org/10.1016/j. carbpol.2016.03.020

Liu X, He X, Mao W, Cao S, Qin L, He M, He X, Mao W (2018) Anticoagulant properties of a green algal rhamnan-type sulfated polysaccharide and its low-molecular-weight fragments prepared by mild acid degradation. Mar Drugs. https://doi.org/10.3390/md16110445

Majdoub H, Ben M, Chaubet F, Roudesli MS, Maarou RM (2009) Anticoagulant activity of a sulfated polysaccharide from the green alga Arthrospira platensis. Biochem Biophys Acta 1790:1377-1381. https://doi.org/10.1016/j. bbagen.2009.07.013

Mao WJ, Fang F, Li HY, Qi XH, Sun HH, Chen Y, Guo SD (2008) Heparinoid-active two sulfated polysaccharides isolated from marine green algae Monostroma nitidum. Carbohyd Polym 74:834-839. https://doi.org/10.1016/j. carbpol.2008.04.041

Marques J, Vilanova E, Mourão PAS, Fernàndez-Busquets X (2016) Marine organism sulfated polysaccharides exhibiting significant antimalarial activity and inhibition of red blood cell invasion by Plasmodium. Sci Rep 6:1-14. https://doi.org/10.1038/srep24368

McCann MC, Hammouri M, Wilson R, Belton P, Roberts K (1992) Fourier transform infrared microspectroscopy is a new way to look at plant cell walls. Plant Physiol 100:1940-1947. https://doi.org/10.1104/pp.100.4.1940

Mervat HH, Ghada SA-E, Sami AS-D, Nagwa IH (2015) Characterization and antioxidant activity of exopolysaccharide secreted by nostoc carneum. Int J Pharmacol 11:432-439. https://doi.org/10.3923/ijp.2015.432.439

Minhas AK, Hodgson P, Barrow CJ, Sashidhar B, Adholeya A (2016) The isolation and identification of new microalgal strains producing oil and carotenoid simultaneously with biofuel potential. Biores Technol 211:556-565. https://doi.org/10.1016/j.biortech.2016.03.121

Mišurcová L, Orsavová J, Ambrožová JV (2015) Algal polysaccharides and health. In: Ramawat KG, Mérillon J-M (eds) Polysaccharides: bioactivity and biotechnology. Springer, Berlin, pp 109-144

Mourão PAS (2015) Perspective on the use of sulfated polysaccharides from marine organisms as a source of new antithrombotic drugs. Mar Drugs 13:2770-2784. https://doi.org/10.3390/md13052770

Nishino T, Nagumo T (1992) Anticoagulant and antithrombin activities of oversulfated fucans. Carbohydr Res 229:355-362

Ortiz-tena JG, Rühmann B, Schieder D, Sieber V (2016) Revealing the diversity of algal monosaccharides : Fast carbohydrate fingerprinting of microalgae using crude biomass and showcasing sugar distribution in Chlorella vulgaris by biomass fractionation. Algal Res 17:227-235. https://doi.org/10.1016/j.algal.2016.05.008

Periasamy A, Muruganand S, Palaniswamy M (2009) Vibrational studies of $\mathrm{Na}_{2} \mathrm{SO}_{4}, \mathrm{~K}_{2} \mathrm{SO}_{4}, \mathrm{NaHSO}_{4}$ and $\mathrm{KHSO}_{4}$ crystals. Rasayan J Chem 2:981-989

Pierre G, Delattre C, Dubessay P, Jubeau S, Vialleix C, Cadoret JP, Probert I, Michaud P (2019) What is in store for EPS microalgae in the next decade? Molecules 24:1-25. https://doi.org/10.3390/molecules24234296

Qi H, Zhang Q, Zhao T, Chen R, Zhang H, Niu X, Li Z (2005) Antioxidant activity of different sulfate content derivatives of polysaccharide extracted from Ulva pertusa (Chlorophyta) in vitro. Int J Biol Macromol 37:195199. https://doi.org/10.1016/j.ijbiomac.2005.10.008

Romano CS, Abadi K, Repetto V, Vojnov AA, Moreno S (2009) Synergistic antioxidant and antibacterial activity of rosemary plus butylated derivatives. Food Chem 115:456-461. https://doi.org/10.1016/j.foodc hem.2008.12.029

Salerno GL, Pontis HG (1989) Raffinose synthesis in Chlorella vulgaris cultures after a cold shock. Plant Physiol 89:648-651

Schulze C, Strehle A, Merdivan S, Mundt S (2017) Carbohydrates in microalgae: comparative determination by TLC, LC-MS without derivatization, and the photometric thymol-sulfuric acid method. Algal Res 25:372-380. https://doi.org/10.1016/j.algal.2017.05.001

Seedevi P, Moovendhan M, Viramani S, Shanmugam A (2016) Bioactive and structural chracterization of sulfated polysaccharide from seaweed (Gracilaria Corticata). Carbohyd Polym. https://doi.org/10.1016/j.carbp ol.2016.09.011

Song H, He M, Gu C, Wei D, Liang Y, Yan J, Wang C (2018) Extraction optimization, purification, antioxidant activity, and preliminary structural characterization of crude polysaccharide from an arctic Chlorella sp. Polymers. https://doi.org/10.3390/polym10030292

Suárez ER, Kralovec JA, Noseda MD, Ewart HS, Barrow CJ, Lumsden MD, Grindley TB (2005) Isolation, characterization and structural determination of a unique type of arabinogalactan from an immunostimulatory extract of Chlorella pyrenoidosa. Carbohyd Res 340:1489-1498. https:// doi.org/10.1016/j.carres.2005.04.003

Sui Z, Gizaw Y, Bemiller JN (2012) Extraction of polysaccharides from a species of Chlorella. Carbohyd Polym 90:1-7. https://doi.org/10.1016/j. carbpol.2012.03.062

Sun M-L, Zhao F, Shi M, Zhang X-Y, Zhou B-C, Zhang Y-Z, Chen X-L (2015) Characterization and biotechnological potential analysis of a new exopolysaccharide from the Arctic Marine Bacterium Polaribacter sp. SM1127. Sci Rep 5:1-12. https://doi.org/10.1038/srep18435

Wang X, Zhang Z, Yao Z, Zhao M, Qi H (2013) Sulfation, anticoagulant and antioxidant activities of polysaccharide from green algae Enteromorpha linza. Int J Biol Macromol 58:225-230. https://doi.org/10.1016/j.ijbio mac.2013.04.005

Wang J, Sun X, Ouyang J (2018) Structural characterization, antioxidant activity and biomedical application of astragalus polysaccharide degradation products. Int J Polym Sci. https://doi.org/10.1155/2018/5136185

Wang W-N, Li T, Li Y, Zhang Y, Wu HL (2022) Exopolysaccharides from the energy microalga strain. Foods. https://doi.org/10.3390/foods11010110

Wu S, Gong G, Wang Y, Li F, Jia S, Qin F, Ren H, Liu Y (2013) Response surface optimization of enzyme-assisted extraction polysaccharides from Dictyophora indusiata. Int J Biol Macromol 61:63-68. https://doi.org/10. 1016/j.ijbiomac.2013.06.036

Wu GJ, Shiu SM, Hsieh MC, Tsai GJ (2015) Anti-inflammatory activity of a sulfated polysaccharide from the brown alga Sargassum cristaefolium. Food Hydrocolloids. https://doi.org/10.1016/j.foodhyd.2015.01.019 
Yang J, Du Y, Huang R, Wan Y, Li T (2002) Chemical modification, characterization and structure-anticoagulant activity relationships of Chinese lacquer polysaccharides. Int J Biol Macromol 31:55-62. https://doi.org/ 10.1016/S0141-8130(02)00066-1

Yuan Q, Li H, Wei Z, Lv K, Gao C, Liu Y, Zhao L (2020) Isolation, structures and biological activities of polysaccharides from Chlorella: a review. Int J Biol Macromol 163:2199-2209. https://doi.org/10.1016/j.ijbiomac.2020. 09.080

Zhang Z, Wang X, Zhao M, Yu S, Qi H (2013) The immunological and antioxidant activities of polysaccharides extracted from Enteromorpha linza. Int J Biol Macromol 57:45-49. https://doi.org/10.1016/j.ijbiomac.2013.03.006

Zhang J, Liu L, Ren Y, Chen F (2019) Characterization of exopolysaccharides produced by microalgae with antitumor activity on human colon cancer cells. Int J Biol Macromol 128:761-767. https://doi.org/10.1016/j.ijbiomac. 2019.02.009

\section{Publisher's Note}

Springer Nature remains neutral with regard to jurisdictional claims in published maps and institutional affiliations.

\section{Submit your manuscript to a SpringerOpen ${ }^{\odot}$ journal and benefit from:}

- Convenient online submission

- Rigorous peer review

- Open access: articles freely available online

- High visibility within the field

- Retaining the copyright to your article

Submit your next manuscript at $\boldsymbol{\nabla}$ springeropen.com 